\title{
Primary hepatic lymphoma: is it a disease entity?
}

\author{
Fei Xiong, Yong-Song Guan \\ Department of Oncology, West China Hospital of Sichuan University, Chengdu 610041, Sichuan, China.
}

Correspondence to: Prof. Yong-Song Guan, Department of Oncology, West China Hospital of Sichuan University, 37 Guo Xue Xiang Street, Chengdu 610041, Sichuan, China. E-mail: yongsongguan@yahoo.com

How to cite this article: Xiong F, Guan YS. Primary hepatic lymphoma: is it a disease entity? Hepatoma Res 2017;3:73-8.

\begin{tabular}{l} 
Article history: \\
Received: $15-01-2017$ \\
Accepted: $24-03-2017$ \\
Published: $09-05-2017$ \\
\hline Key words: \\
Lymphoma, \\
primary, \\
hepatic, \\
diagnosis, \\
entity
\end{tabular}

\begin{abstract}
It is now widely accepted that lymphoma is a cancer of the lymphatic cells in the immune system and a type of blood cancer that develops when $\mathrm{T}$ or B lymphocytes of the white blood cells display uncontrolled proliferation and cellular immortality. Currently, a number of authors have published case reports or case series in which these lesions are defined as primary hepatic lymphoma. This minireview discusses several aspects of the entity of primary hepatic lymphoma, especially the dilemmas in diagnosis.
\end{abstract}

\section{INTRODUCTION}

Malignant lymphoma is a tumor disease originated from hematopoietic cells typically presented as an apparently circumscribed solid tumor of lymphoid cells. ${ }^{[1,2]}$ It is now widely accepted that lymphoma is a cancer of the lymphatic cells in the immune system which protect the body against diseases and infection. It is a type of blood cancer that develops when $T$ or B lymphocytes of the white blood cells display uncontrolled proliferation and cellular immortality. ${ }^{[3,4]}$ Lymphoma is composed of cells that look naïve or resemble lymphocytes, histiocytes or plasma cells. ${ }^{[5,6]}$ Sometimes the origin of the lymphoma can not be simply decided, like in the instance of natural killer- cell lymphoma or immunodeficiency-associated lymphoproliferative disorders. ${ }^{[7,8]}$ Lymphomas are usually seen in lymph nodes, spleen, blood, bone marrow, brain, gastrointestinal tract and skin or other normal structures where lymphoreticular cells exist, but very rarely in the liver. ${ }^{[9-11]}$ Lymphomas with disseminated disease may enter the blood stream and present as leukemia, notably of the lymphocytic type..$^{[12,13]}$ The classification of lymphoma is based on clinical manifestation, cell morphology, cytochemistry, genetics and immunophenotype to determine the entity with clinical significance. ${ }^{[13]}$ With the advance in imaging technology, more and more lesions of lymphoma were detected involving the liver at presentation. ${ }^{[14]}$ Currently, a number of authors have published case reports or case series 
in which these lesions are defined as primary hepatic lymphoma and described as a malignancy that is very rare and frequently misdiagnosed, but has a rather better prognosis by the combination of surgery and chemotherapy as the treatment than primary hepatic carcinoma. ${ }^{[15-17]}$ This paper discusses several aspects of the entity of primary hepatic lymphoma, especially the dilemmas in diagnosis.

\section{CLASSIFICATION OF LYMPHOMA}

In 1965, Ata et al. ${ }^{[18]}$ reported, for the first time, a case of primary reticulum cell sarcoma of the liver. Later in 1971, Torres et al. ${ }^{[19]}$ described primary reticulum cell sarcoma of liver in cancer. Since then, cases and case series have been accumulated reporting the characteristics of primary hepatic lymphoma and stating that this disease is extremely rare with the absence of lymphoproliferative disease outside the liver. ${ }^{[20,21]}$

Some authors defined primary hepatic lymphoma as a very rare malignant tumor with the features of liver involvement and without involvement of other organs and tissues including bone marrow, lymph nodes, the spleen and peripheral blood until at least 6 months after diagnosis. ${ }^{[14,22]}$ However, Caccamo's criteria which many authors have cited for the diagnosis of primary hepatic lymphoma were proposed in 1986 and based on the data of a single patient who was complicated with liver cirrhosis, Kaposi's sarcoma, and involvement of gastric mucosa and abdominal lymph nodes. ${ }^{[22,23]}$ In many of the case reports, the patient follow-up was not long enough as "at least 6 months after diagnosis" and some diagnoses were determined just after the biopsy even when there were enlarged retroperitoneal lymph nodes and bone marrow infiltration by lymphoma. ${ }^{[11,14,15]}$

Is there indeed a disease entity named primary hepatic lymphoma? The definition of the word or special term "primary" is the key point to answer the question. The authors of this paper consulted several dictionaries and encyclopedias including online medical dictionaries, especially the National Institutes of Health's Web site, i.e. MedlinePlus, produced by the National Library of Medicine. ${ }^{[24]}$ The definition of the word "PRIMARY" can be summarized in two explanations. The first one is general: first in order of time, place, development, or importance. However the second is medical: not derived from any other source or cause, especially the original condition or a group of symptoms in disease processes, such as a primary infection or a primary tumor, arising spontaneously (idiopathic, efforts to find the original tumor have failed), being an initial tumor or place specifically of cancer. ${ }^{[24]}$

Some authors stated that primary hepatic lymphoma should be differentiated from hepatitis, hepatic metastasis, primary hepatic tumors and secondary hepatic lymphoma, however, they attempted to prove that a liver lymphoma was primary even when bone marrow or portal lymph nodes were involved and interpreted that this involvement was metastasis but not infiltration. ${ }^{[25,26]}$

Secondary hepatic lymphomas are defined by some authors as liver lymphomas with extra hepatic foci of lymphoma and found at the first onset or afterwards, or systemic lymphoma with secondary hepatic involvement. This description is also conflicting with the above definition of primary lymphoma. ${ }^{[2]]}$

The WHO classification of lymphoma is the generally accepted interpretation. In this system, lymphomas are classified by the normal cell type that looks most like the tumor and interpreting cytogenetic, molecular or phenotypic features. ${ }^{[28]}$ The three main groups are the $\mathrm{T}$ cell, $\mathrm{B}$ cell, and natural killer cell lymphomas. Less common groups are identified and listed in the subtypes. It has been debated that this classification needs validating in a large series of patients before publication. ${ }^{[2,3]}$ Interestingly in this classification, the term "primary" is used but not specified, like primary effusion lymphoma, primary central nervous system lymphoma, etc., and a number of subtypes are described as "provisional entities" [Table 1].

\section{ESTABLISHMENT OF DIAGNOSIS}

Clinical manifestations usually suggest diseases involving the liver but not the lymphatic and immune system. ${ }^{[29,30]}$ Many cases are diffuse large B cell lymphoma and the patients show B-symptomatology of weight loss, fever, and night sweats, as well as fatigue and lethargy. ${ }^{[26]}$ Laboratory study on hepatitis virus infection and serum I-lactate dehydrogenase provides reference to treatment rather than diagnosis of lymphoma. Serum levels of $\alpha$-fetoprotein and other common tumor markers are usually normal. ${ }^{[1,32]}$ Imaging modalities are very important tools for detecting liver tumors and lymphoma, although the majority of the diagnoses of liver lymphoma are established afterwards which is quite different from the imaging diagnosis of mediastinal or retroperitoneal lymphoma. ${ }^{[33]}$

\section{Image modalities}

For evaluating primary liver tumors, currently useful image modalities include ultrasound, computed 
Table 1: WHO classification subtypes of lymphoma

\begin{tabular}{|c|c|}
\hline Subtypes & Group members \\
\hline Mature B-cell neoplasms & $\begin{array}{l}\text { ALK+ large B-cell lymphoma } \\
\text { B-cell prolymphocytic leukemia } \\
\text { Burkitt lymphoma/leukemia } \\
\text { B-cell chronic lymphocytic leukemia/small cell lymphoma } \\
\text { Diffuse large B cell lymphoma } \\
\text { Epstein-Barr virus-positive diffuse large B-cell lymphoma of the elderly } \\
\text { Extranodal marginal zone B cell lymphoma (mucosa-associated lymphoid tissue lymphoma) } \\
\text { Follicular lymphoma } \\
\text { Hairy cell leukemia } \\
\text { Intravascular large B cell lymphoma } \\
\text { Lymphoplasmacytic lymphoma } \\
\text { Mantle cell lymphoma } \\
\text { Nodal marginal zone B cell lymphoma } \\
\text { Plasma cell neoplasms } \\
\text { Plasmablastic lymphoma } \\
\text { Primary cutaneous follicle center lymphoma } \\
\text { Primary mediastinal (thymic) large B-cell lymphoma } \\
\text { Splenic marginal zone lymphoma }\end{array}$ \\
\hline $\begin{array}{l}\text { Mature T cell and natural killer (NK) cell } \\
\text { neoplasms }\end{array}$ & $\begin{array}{l}\text { Adult T cell leukemia/lymphoma } \\
\text { Anaplastic large cell lymphoma } \\
\text { Aggressive NK cell leukemia } \\
\text { Angioimmunoblastic T cell lymphoma } \\
\text { Blastic NK cell lymphoma } \\
\text { Enteropathy-associated T-cell lymphoma } \\
\text { Extranodal NK/T-cell lymphoma, nasal type } \\
\text { Hepatosplenic T-cell lymphoma } \\
\text { Mycosis fungoides/Sezary syndrome } \\
\text { Peripheral T-cell lymphoma not otherwise specified } \\
\text { Primary cutaneous CD30-positive T-cell lymphoproliferative disorders } \\
\text { T-cell large granular lymphocytic leukemia } \\
\text { T-cell prolymphocytic leukemia }\end{array}$ \\
\hline Hodgkin lymphoma & $\begin{array}{l}\text { Classical Hodgkin lymphomas } \\
\text { Lymphocyte depleted or not depleted } \\
\text { Lymphocyte-rich } \\
\text { Mixed cellularity } \\
\text { Nodular sclerosis } \\
\text { Nodular lymphocyte-predominant Hodgkin lymphoma }\end{array}$ \\
\hline $\begin{array}{l}\text { Immunodeficiency-associated } \\
\text { lymphoproliferative disorders }\end{array}$ & $\begin{array}{l}\text { Associated with a primary immune disorder } \\
\text { Associated with methotrexate therapy } \\
\text { Associated with the human immunodeficiency virus } \\
\text { Post-transplant } \\
\text { Primary central nervous system lymphoma }\end{array}$ \\
\hline
\end{tabular}

tomography (CT), magnetic resonance imaging (MRI), positron emission tomography and computed tomography (PET/CT), and digital subtraction angiography (DSA). The following description of these modalities is mainly based on the results from retrospective studies. ${ }^{[34]}$

Ultrasound is the most sensitive of image modalities to find liver lymphoma showing hypoechoic liver lesion with irregular margins. When contrast is used, the tumor is inhomogeneously hyperenhanced in the arterial phase and hypoenhanced in the portal and late phases, similar to the images of hepatocellular carcinoma. ${ }^{[35]}$

Lymphomas detected in the liver by plain CT scan usually present as homogeneous shadows of low density, with irregular demarcations. ${ }^{[16]}$ A very low density area in the center might indicate necrosis. When 3-phase contrast-enhanced scan is used, the lesions will not be enhanced at the arterial and portal phase, and will be slightly enhanced at the delayed phase with a border sharply contrasted with the normal neighboring tissue. ${ }^{[24]}$ Some liver lymphomas reported as primary or secondary may shrink or vanish after treatment when demonstrated by CT scan, but no change in density or enhancement of the remaining lesions are found. In addition, diffuse liver infiltration by lymphoma can be detected by CT scan only when there are areas of density change in the swelling liver. But lymphoma infiltration without density change in an enlarged liver cannot be revealed by CT. It is impossible, of course, to definitely exclude lymphoma infiltration within a liver which is normal in size and CT density. CT is now commonly used for lymphoma staging. ${ }^{[15,36]}$

Liver lymphomas present heterogeneous signals on MRI image with features of hypointense in T1weighted sequences but hyperintense in T2-weighted sequences. ${ }^{[3]}$ Although $\mathrm{MRI}$ has the advantage in specifically characterizing liver lesions over all other imaging modalities, it often fails to distinguish primary hepatic lymphoma from other liver masses. ${ }^{[37]}$ In a report, MRI presented almost the same imaging features for lymphoma and sarcoidosis. ${ }^{[11]}$ 
Table 2: Several pathological subtypes of lymphomas and their possible immunophenotypes

\begin{tabular}{lc}
\hline Pathological subtypes & Immunophenotypes \\
\hline B-cell chronic lymphocytic leukemia/lymphoma & CD5, CD19, CD20 \\
Burkitt's lymphoma & BCL6, CD10, CD19, CD20, CD22 \\
Diffuse large B-cell lymphoma & CD4, CD8, CD10 \\
Follicular lymphoma & CD10, CD19, CD20 \\
Mucosa-associated lymphoid tissue lymphoma & CD20, CD45, CD79 \\
Mantle cell lymphoma & CD5, CD19 \\
Mixed-cellularity subtype of Hodgkin lymphoma & CD2, CD4, CD15, CD30 \\
Mycosis fungoides & CD4, CD8 \\
Nodular sclerosis form of Hodgkin lymphoma & CD15, CD20, CD30 \\
Peripheral T-cell lymphoma-not-otherwise-specified & CD3, CD43, CD45, CD45RO \\
Precursor T-cell leukemia/lymphoma & TdT, CD2, CD7, CD45, CD99 \\
\hline
\end{tabular}

PET/CT is used to improve the detection range, response evaluation, and prognosis prediction of lymphoma. With the help of 18F-fluorodeoxyglucose (FDG), this modality provides high sensitivity in evaluating most liver lesions and is invaluable for finding extrahepatic lesions. However, false positive findings are common in inflammatory or metastatic lesions. ${ }^{[38,39]}$ However, the problem of specificity can be partially solved by percutaneous needle biopsy.

Celiac trunk angiography of known lesions shows very scarce contrast staining, tiny feeding arteries, obvious shifting of the hepatic artery/its tributaries, and the absence of enlarged tumor blood vessels. When a small amount of lipiodol is injected into the feeding arteries during the DSA procedure, no deposit of lipiodol can be observed in the lesions. ${ }^{[40]}$

None of the above modalities produce specific image features for the diagnosis of liver lymphoma. Other than explorative laparotomy, puncture biopsy under the guidance of ultrasound or CT is of paramount importance for establishing the diagnosis of liver lymphoma by acquiring specimens for pathological and immunohistochemical examination. ${ }^{[5]}$ Moreover, core puncture needle is much more reliable than fine needle to obtain adequate samples for study. ${ }^{[41]}$

\section{Pathology and immunohistochemistry}

The clinical diagnosis is usually established by a pathologist (commonly a hemato-pathologist) after the examination of the biopsy specimens. ${ }^{[4]}$ Hematoxylin and eosin stain of liver specimen may show infiltration of large lymphoid cells. Immunohistochemistry may show positive Ki67, positive CD3, CD5, CD30, CD40, etc. ${ }^{[39]}$ Fluorescence in situ hybridization is applied for tumor genetics and flow cytometry is used for quantitative analysis of cells. ${ }^{[15]}$ The pathological classification of subtypes is essential for treatment decision and outcome prediction [Table 2]. On the other hand, newly developed lesions in the liver of lymphoma patients can not be the same disease, as other kinds of tumor may occur because of immune compromise or liver diseases. ${ }^{[42]}$

\section{CONCLUSION}

Liver is a poor "soil" for malignant lymphoma as a "seed" to grow. Most reports about primary hepatic lymphoma are published in the form of case studies and no prospective researches have been found till now. It is difficult for the radiologist to define lymphomas in the liver as primary or secondary, even when they really are lymphomas. The differentiation of primary lymphoma from secondary also puzzles the pathologist and all involved multidisciplinary oncological specialists. That another malignant tumor may develop in the liver of patients with lymphomas makes things more complicated.

Most of the reported cases are diffuse large B cell lymphomas but this type is usually aggressive and involves multiple organs. In addition, according to the above definition provided by some authors, the establishment of the diagnosis of primary hepatic lymphoma is a retrospective process that should be decided at least 6 months after the initial diagnosis of lymphoma. So, the diagnosis of primary hepatic lymphoma at first liver biopsy is problematic and conflicting with this definition.

Lymphomas are often detected in the liver by CT incidentally or general screening for lesions in the patients. The term "primary hepatic lymphoma" is imprecise and less informative for referral to a proper treatment and can be confused with the subtype hepatosplenic T cell lymphoma of WHO classification. Current criteria for the diagnosis of primary hepatic lymphoma are outdated. The differentiation must be made between primary and secondary disease at first, and efforts should be directed to find the original tumor. This "provisional entity" is still controversial, and additional researches and discussions on criteria for its diagnosis are warranted to clarify their significance for consensus and refinement.

\section{Authors' contributions}

Collection of literature data: F. Xiong

Design, writing and revision of the paper: Y.S. Guan 


\section{Financial support and sponsorship None.}

\section{Conflicts of interest \\ There are no conflicts of interest.}

\section{Patient consent}

There is no patient involved.

\section{Ethical approval}

This review paper is waived for ethics approval.

\section{REFERENCES}

1. Vardiman JW, Thiele J, Arber DA, Brunning RD, Borowitz MJ, Porwit A, Harris NL, Le Beau MM, Hellström-Lindberg E, Tefferi A, Bloomfield CD. The 2008 revision of the World Health Organization (WHO) classification of myeloid neoplasms and acute leukemia: rationale and important changes. Blood 2009;114:937-51.

2. Găman $M$,Vlădăreanu $\mathrm{AM}$, Radesi $\mathrm{S}$. The implications of revised WHO classification (2008) of chronic myeloid neoplasms. Rom J Intern Med 2011;49:25-30.

3. Vardiman JW, Harris NL, Brunning RD. The World Health Organization (WHO) classification of the myeloid neoplasms. Blood 2002;100:2292-302.

4. Pileri SA. "Old" is "new" in diagnostic pathology. Hum Pathol 2013;44:1705-6.

5. Liu YH, Zhuang HG, Lin HL, Wu QL, Luo DL, Li L, Luo XL. Differential diagnosis between nodular lymphocyte-predominant Hodgkin lymphoma and T-cell/histiocyte-rich B-cell lymphoma. Zhonghua Zhong Liu Za Zhi 2006;28:594-8.

6. Lukes RJ, Collins RD. New approaches to the classification of the lymphomata. Br J Cancer Suppl 1975;2:1-28.

7. Roy AD, Tuli IP, Joshi D. NK/T cell lymphoma with inverted papilloma: a rare coexistence. Australas Med J 2014;7:318-22.

8. Knowles DM. Immunodeficiency-associated lymphoproliferative disorders. Mod Pathol 1999;12:200-17.

9. Frimmel SA, Kniestedt C, Töteberg-Harms M, Chaloupka K. Lymphoma of the ocular adnexa. Klin Monbl Augenheilkd 2014;231:394-404.

10. Shakya VC, Agrawal CS, Sah P, Pradhan A, Adhikary S. Rare location of primary non-Hodgkin's lymphoma in the rectum. JNMA J Nepal Med Assoc 2013;52:508-11.

11. Do TD, Neurohr C, Michl M, Reiser MF, Zech CJ. An unusual case of primary hepatic lymphoma mimicking sarcoidosis in MRI. Acta Radiol Short Rep 2014;3:2047981613493625.

12. Liu Y, Zhang W, An J, Li H, Liu S. Cutaneous intravascular natural killer-cell lymphoma: a case report and review of the literature. $\mathrm{Am} J$ Clin Pathol 2014;142:243-47.

13. Vardiman JW. The World Health Organization (WHO) classification of tumors of the hematopoietic and lymphoid tissues: an overview with emphasis on the myeloid neoplasms. Chem Biol Interact 2010;184:16-20.

14. Mastoraki A, Stefanou MI, Chatzoglou E, Danias N, Kyriazi M, Arkadopoulos N, Smyrniotis V. Primary hepatic lymphoma: dilemmas in diagnostic approach and therapeutic management. Indian J Hematol Blood Transfus 2014;30:150-4.

15. Masood A, Kairouz S, Hudhud KH, Hegazi AZ, Banu A, Gupta NC. Primary non-Hodgkin lymphoma of liver. Curr Oncol 2009;16:74-7.

16. Zafar MS, Aggarwal S, Bhalla S. Complete response to chemotherapy in primary hepatic lymphoma. $J$ Cancer Res Ther 2012;8:114-6.
17. Bouliaris K, Christodoulidis G, Koukoulis G, Mamaloudis I, Ioannou M, Bouronikou E, Palassopoulou M, Tepetes K. A primary hepatic lymphoma treated with liver resection and chemotherapy. Case Rep Surg 2014;2014:749509.

18. Ata AA, Kamel IA. Primary reticulum cell sarcoma of the liver. A case report. J Egypt Med Assoc 1965;48:514-21.

19. Torres A, Bollozos GD. Primary reticulum cell sarcoma of liver. Cancer 1971;27:1489-92.

20. Resende V, Oliveira TS, Gomes RT, Laboissière RS, Tavares-Junior WC, de Melo Couto OF. Primary hepatic lymphoma: a case report. Int J Surg Case Rep 2013;4:1165-8.

21. Ma YJ, Chen EQ, Chen XB, Wang J, Tang H. Primary hepatic diffuse large B cell lymphoma: a case report: primary hepatic diffuse large B cell lymphoma. Hepat Mon 2011;11:203-5.

22. Caccamo D, Pervez NK, Marchevsky A. Primary lymphoma of the liver in the acquired immunodeficiency syndrome. Arch Pathol Lab Med 1986;110:553-5.

23. Raimondo L, Ferrara I, Stefano AD, Cella CA, D'Armiento FP, Ciancia G, Moretto R, Renzo AD, Carlomagno C. Primary hepatic lymphoma in a patient with previous rectal adenocarcinoma: a case report and discussion of etiopathogenesis and diagnostic tools. Int $J$ Hematol 2012;95:320-3.

24. U.S. National Library of Medicine. MedlinePlus. Available from: http:// www.nlm.nih.gov/medlineplus/. [Last accessed on April 14, 2017]

25. Ryan J, Straus DJ, Lange C, Filippa DA, Botet JF, Sanders LM, Shiu MH, Fortner JG. Primary lymphoma of the liver. Cancer 1988;61:370-5.

26. Osborne BM, Butler JJ, Guarda LA. Primary lymphoma of the liver. Ten cases and a review of the literature. Cancer 1985;56:2902-10.

27. Swadley MJ, Deliu M, Mosunjac MB, Gunthel CJ, Nguyen ML, Hanley KZ. Primary and secondary hepatic lymphomas diagnosed by image-guided fine-needle aspiration: a retrospective study of clinical and cytomorphologic findings. Am J Clin Pathol 2014;141:119-27.

28. Swerdlow SH, Campo E, Harris NL, Jaffe ES, Pileri SA, Stein H, Thiele J, Vardiman JW; International Agency for Research on Cancer, World Health Organization (IARC). WHO classification of tumours of haematopoietic andlymphoid tissues. Lyon: IARC Press; 2008. p. 439.

29. Mishra S, Shukla A, Tripathi AK, Kumar A. Primary T-cell lymphoma of liver. BMJ Case Rep 2013;2013:pii: bcr2012008467.

30. Cerban R, Gheorghe L, Becheanu G, Serban V, Gheorghe C. Primary focal T-cell lymphoma of the liver: a case report and review of the literature. J Gastrointestin Liver Dis 2012;21:213-6.

31. Kaneko F, Yokomori H, Sato A, Takeuchi H, Tahara K, Sekiguchi Y, Mori S, Motoori T, Kondo H, Hibi T. A case of primary hepatic nonHodgkin's lymphoma with chronic hepatitis C. Med Mol Morphol 2008;41:171-4.

32. Takeuchi N, Naba K. Primary hepatic lymphoma is difficult to discriminate from a liver abscess. Case Rep Gastrointest Med 2014;2014:925307.

33. Maher MM, McDermott SR, Fenlon HM, Conroy D, O'Keane JC, Carney DN, Stack JP. Imaging of primary non-Hodgkin's lymphoma of the liver. Clin Radiol 2001;56:295-301.

34. Mohamed M, Fernando R. Diagnostic and therapeutic quandaries in a patient with primary hepatic lymphoma and concurrent hepatitis $\mathrm{C}$ infection. Indian J Hematol Blood Transfus 2014;30:394-7.

35. Foschi FG, Dall'Aglio AC, Marano G, Lanzi A, Savini P, Piscaglia F, Serra C, Cursaro C, Bernardi M, Andreone P, Stefanini GF. Role of contrast-enhanced ultrasonography in primary hepatic lymphoma. $J$ Ultrasound Med 2010;29:1353-6.

36. Myoteri D, Dellaportas D, Arkoumani E, Marinis A, ZiziSermpetzoglou A. Primary hepatic lymphoma: a challenging diagnosis. Case Rep Oncol Med 2014;2014:212598.

37. Roth CG, Mitchell DG. Hepatocellular carcinoma and other hepatic 
malignancies: MR imaging. Radiol Clin North Am 2014;52:683-707.

38. Tan GJ, Berlangieri SU, Lee ST, Scott AM. FDG PET/CT in the liver: lesions mimicking malignancies. Abdom Imaging 2014;39:187-95.

39. Doi H, Horiike N, Hiraoka A, Koizumi Y, Yamamoto Y, Hasebe A, Ichikawa S, Yano M, Miyamoto Y, Ninomiya T, Ishimaru Y, Miyagawa M, Takamura K, Kawasaki H, Kozuka T, Maeda T, Yoshino T. Primary hepatic marginal zone B cell lymphoma of mucosa-associated lymphoid tissue type: case report and review of the literature. Int $J$ Hematol 2008;88:418-23.

40. Liu FY, Chen D, Shang JB, Wu XM, Zhang XL. Clinical and imaging diagnosis of primary hepatic lymphoma. Di Yi Jun Yi Da Xue Xue Bao
2005;25:1290-2

41. El-Sharkawi D, Ramsay A, Cwynarski K, Hughes D, Prentice A, Davies N, Goode A, Wylie P, Malhotra A, Warbey V, Dooley J, McNamara C. Clinico-pathologic characteristics of patients with hepatic lymphoma diagnosed using image-guided liver biopsytechniques. Leuk Lymphoma 2011;52:2130-4.

42. Civardi G, Vallisa D, Bertè R, Lazzaro A, Moroni CF, Cavanna L. Focal liver lesions in non-Hodgkin's lymphoma: investigation of their prevalence, clinical significance and the role of hepatitis $\mathrm{C}$ virus infection. Eur J Cancer 2002;38:2382-7. 